\title{
PELATIHAN PENGGUNAAN GEOGEBRA SEBAGAI UPAYA UNTUK MENINGKATKAN PROFESIONALISME GURU SMP/MTS DI KECAMATAN SINDANG INDRAMAYU
}

\author{
Runisah, Denni Ismunandar, Farid Gunadi, Luthfiyati Nurafifah \\ Runisah_69@yahoo.co.id, denniismunandar@gmail.com, \\ gunadi_farid@yahoo.com, luthfiyatinurafifah@unwir.ac.id
}

\begin{abstract}
Abstrak
Sebagai Mitra dalam kegiatan PKM ini adalah Kelompok guru yang tergabung dalam Musyawarah Guru Mata Pelajaran (MGMP) Matematika SMP dan MTs Kabupaten Indramayu. Beberapa permasalahan yang dialami oleh guru MGMP yaitu pengetahuan dan kemampuan guru yang kurang dalam memanfaatkan software-software matematika dalam pembelajaran, khususnya software GeoGebra. Tujuan dari pengabdian masyarakat ini adalah:1) untuk meningkatkan pengetahuan dan pemahaman guru tentang pentingnya media dalam pembelajaran matematika; 2) untuk menghasilkan Guru yang mampu mendesain pembelajaran matematika dengan menggunakan software GeoGebra. GeoGebra dipilih sebagai alternatif karena memiliki berbagai keunggulan baik secara teoritis maupun didasarkan hasil penelitian. Metode yang digunakan adalah pelatihan tentang GeoGebra, simulasi, dan evaluasi. Kegiatan PKM dilaksanakan pada Guru anggota MGMP Matematika MTs dan SMP Kecamatan Sindang, Kabupaten Indramayu. Berdasarkan hasil pelatihan ini disimpulkan bahwa pengetahuan dan pemahaman guru tentang pentingnya media dalam pembelajaran matematika meningkat dan Guru yang mampu mendesain pembelajaran matematika dengan menggunakan software GeoGebra.
\end{abstract}

Kata Kunci : desain pembelajaran matematika, GeoGebra, MGMP. 


\section{A. PENDAHULUAN}

\section{Analisis Situasi}

Pada abad XXI perkembangan teknologi begitu cepat dalam berbagai bidang kehidupan, khususnya dalam bidang pendidikan. Dalam bidang pendidikan khususnya dalam pembelajaran di sekolah, Teknologi Informasi (TI) dapat dimanfaatkan sebagai teknologi utama maupun teknologi pendukung. Sebagai teknologi utama, TI difungsikan sesuai dengan materi pelajaran dan sebagai teknologi interaksi pembelajaran antara guru dan siswa. Sedangkan sebagai teknologi pendukung, TI digunakan sebagai media pembelajaran dan sebagai fasilitas pembelajaran. Pola pemanfaatan TI dalam pembelajaran digambarkan sebagai berikut:

\section{TEKNOLOGI UTAMA}

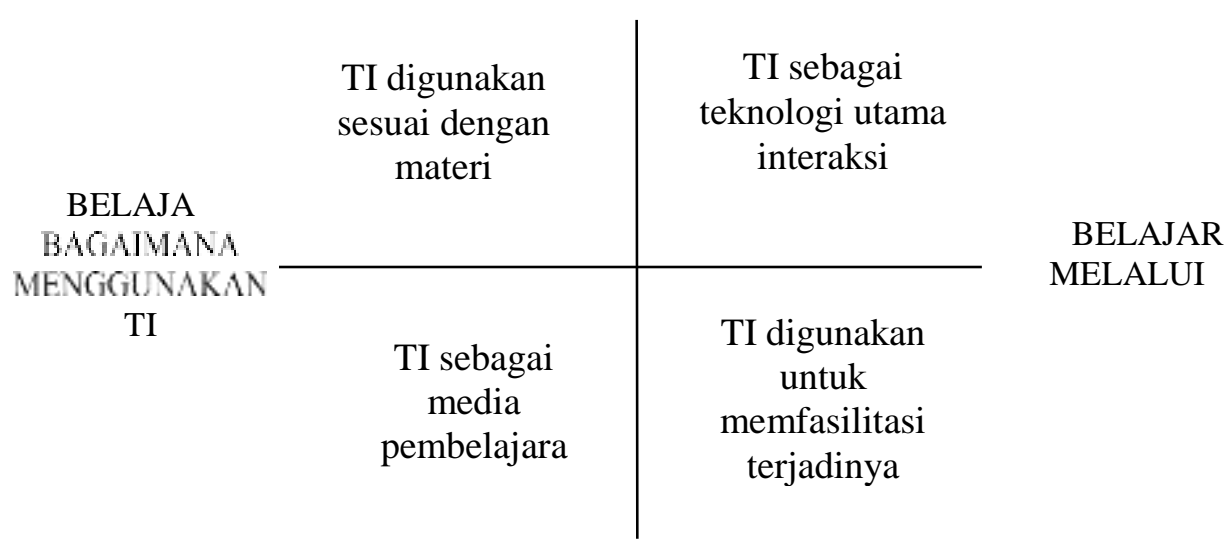

\section{TEKNOLOGI PENDUKUNG}

\section{Gambar 1. Pola Pemanfaatan TI dalam Pembelajaran}

Teknologi Informasi merupakan hal yang tidak asing bagi sekolah-sekolah, baik yang berada di kota maupun di daerah pinggiran kota, termasuk bagi SMP dan MTs di Kabupaten Indramayu. Namun pemanfaatan teknologi dalam pembelajaran belum dilakukan secara maksimal oleh guru-guru, khususnya guru matematika. Masalah ini terungkap dari informasi guru-guru matematika yang tergabung dalam MGMP.

MGMP (Musyarawarah Guru Mata Pelajaran) matematika merupakan suatu organisasi guru yang menjadi forum komunikasi yang bertujuan untuk memecahkan masalah yang dihadapi guru dalam pelaksanaan tugasnya sehari-hari di lapangan. MGMP matematika SMP dan MTs beranggotakan guru-guru matematika di Kabupaten Indramayu. Namun demikian, kegiatan yang dilakukan MGMP SMP tersebut biasanya diwakili oleh guru inti sebanyak 25 orang yang merupakan perwakilan guru-guru Matematika SMP di Kabupaten Indramayu. Sedangkan untuk MGMP MTs diwakili oleh 14 orang, hanya pada kegiatan-kegiatan tertentu saja semua anggota MGMP diundang. Kegiatan MGMP SMP dipusatkan di SMPN Unggulan Sindang yang berada di desa Terusan Kecamatan Sindang Kabupaten Indramayu. Sementara MGMP MTs mempunyai sekretariat di MTs N Lohbener 
Kabupaten Indramayu, tepatnya di desa Lohbenar Kecamatan Lohbener Kabupaten Indramayu. Melalui perwakilan guru inilah kegiatan yang dilakukan di forum MGMP disebarluaskan kepada guru-guru lainnya yang ada di berbagai sekolah.

Beberapa kegiatan yang dilakukan diantaranya bedah soal UN dan persiapan untuk uji kompetensi guru (UKG), dan persiapan kegiatan OSN (Olimpiade Sains Nasional), mengadakan tatap muka (TM) guru pembelajar (GP) yaitu guru yang mempunyai nilai UKG rendah $(<55)$, melakukan bedah soal post test GP-TM MGMP Matematika, dan melakukan posttest. Sementara itu, kegiatan yang berkaitan dengan pemanfaatan teknologi khususnya software dalam pembelajaran matematika belum secara khusus dilakukan. Beberapa kegiatan MGMP disajikan pada gambar berikut:
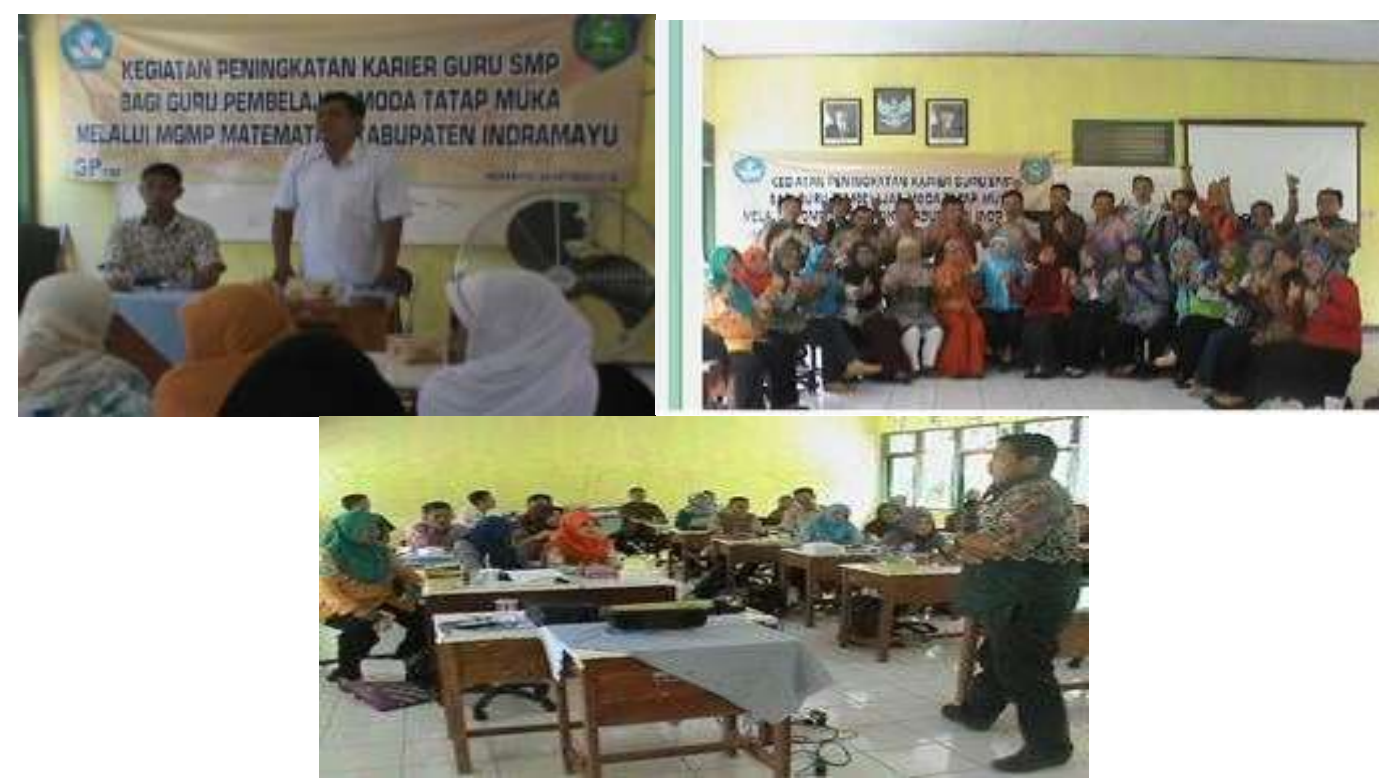

Gambar 2. Kegiatan Tatap Muka (TM) Guru Pembelajar (GP) MGMP Matematika SMP

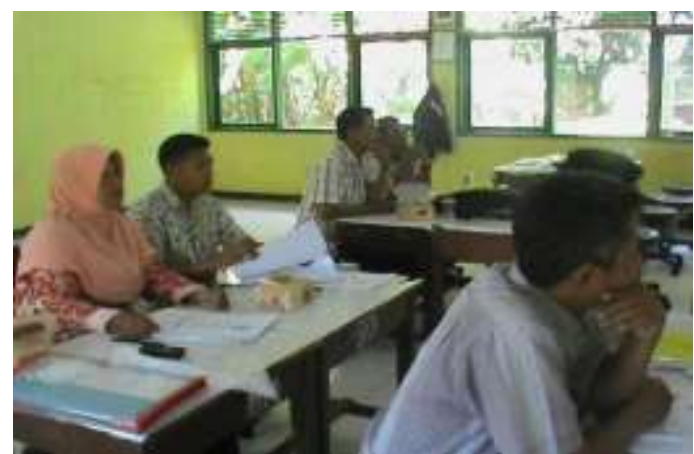

Gambar 3. Kegiatan Bedah Soal Post Test GP-TM MGMP Matematika SMP 


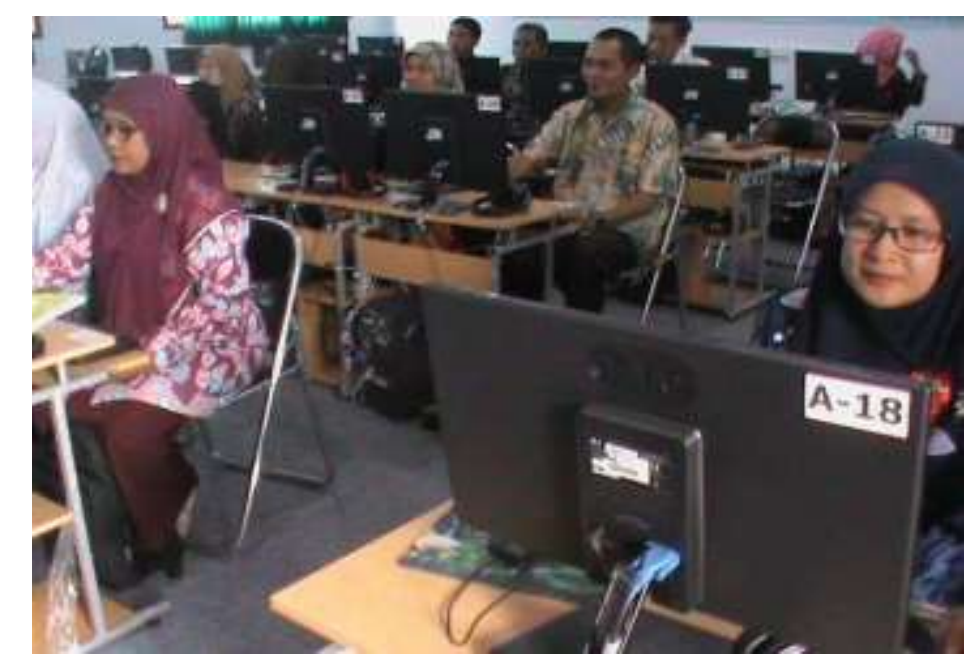

Gambar 4. Kegiatan Postest GP-TM MGMP Matematika SMP



Gambar 5. Kegiatan Pelatihan di MGMP MTs

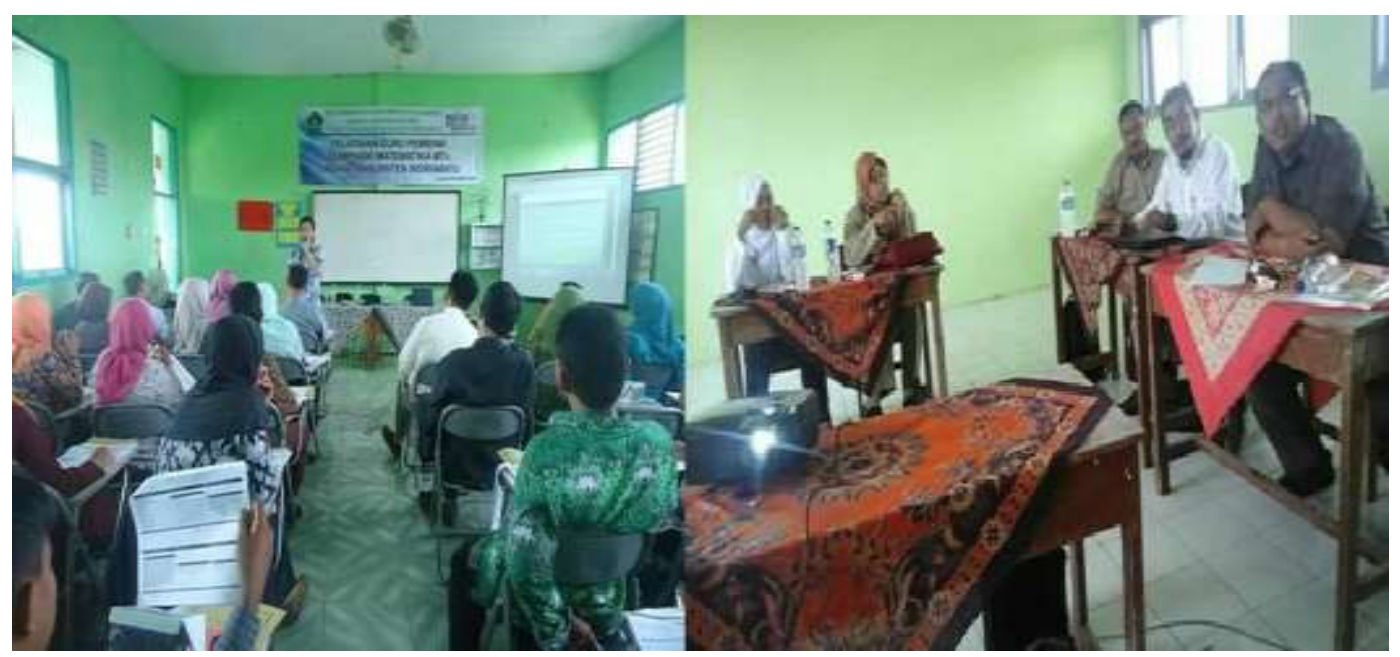

Gambar 6. Pelatihan Guru di MGMP MTs dan Diskusi Kelompok 
Guru-guru matematika yang ada dalam MGMP tersebut sebagian besar masih berpendidikan S1 dan berusia relatif muda yang merupakan usia produktif, yaitu masih memiliki potensi untuk mengikuti perkembangan Teknologi Informasi. Selain itu Guru-guru tersebut memiliki Notebook atau Laptop yang telah menggunakan Modem untuk melakukan koneksi internet. Namun, pemanfaatan IT dalam pembelajaran matematika masih kurang dilakukan. Teknologi belum dimanfaatkan sebagai media eksplorasi dalam pembelajaran Matematika untuk mengembangkan kemampuan berpikir tingkat tinggi siswa guru. Guru matematika hanya memanfaatkan Infokus dalam penyajian materi melalui powerpoint yang dibuat guru. Infokus digunakan dalam presentasi sebagai pengganti papan tulis. Hal ini dikarenakan kurangnya pengetahuan siswa tentang software-software matematika. Sementara itu pihak sekolah tempat guru mengajar juga tidak memiliki petugas khusus yang menangani laboratorium komputer termasuk penggunaan software untuk pembelajaran. Pemanfaatan teknologi di luar kegiatan belajar mengajar di sekolah yang telah berjalan yaitu penggunaan facebook dalam grup MGMP Matematika. Melalui facebook para guru menyajikan pembahasan soal maupun pemberian informasi. Berkaitan dengan pemanfaatan facebook pada grup MGMP disajikan pada gambar berikut:



Gambar 7. Pemanfaatan Facebook dalam grup MGMP Matematika SMP

Pada gambar 7 terlihat guru melakukan pembahasan tentang permasalahan matematika melalui facebook. Dengan dimilikinya laptop dan pemanfaatan infokus sebagai media pembelajaran, serta penggunaan facebook mengindikasikan bahwa sebenarnya motivasi guru dalam pembelajaran dengan memanfaatkan teknologi cukup tinggi.

Sementara itu, sarana yang tersedia di sekolah tempat kegiatan MGMP SMP disamping ruang kelas yang standard, ada laboratorium komputer yang memiliki 25 unit Komputer dan 4 unit Infocus. Selanjutnya, di tempat kegiatan MGMP MTs yaitu di MTs Negeri Lohbener tersedia 100 unit komputer dan 4 infokus. Namun 
baik di MGMP SMP maupun MTs belum ada petugas laboratorium komputer yang khusus menanganinya.

Selanjutnya, menurut informasi dari guru-guru MGMP matematika pada umumnya kemampuan matematika siswa masih rendah, salah satu penyebabnya adalah minat belajar yang rendah. Karena itulah, perlu pemanfaatan teknologi dalam pembelajaran yang berfungsi selain untuk meningkatkan kemampuan berpikir siswa seperti berpikir kritis, kreatif, dan logis, juga diantaranya untuk meningkatkan minatbelajar siswa.

Pemanfaatan teknologi dalam pembelajaran matematika, perlu dirancang khusus agar sesuai dengan materi, prinsip pedagogi, dan menarik bagi siswa. Salah satu software yang memiliki keunggulan sebagai media dalam pembelajaran matematika yaitu GeoGebra. GeoGebra dikembangkan oleh Markus Hohenwarter pada tahun 2001. Keunggulan GeoGebra sebagai program komputer untuk pembelajaran matematika khususnya geometri dan aljabar telah dibuktikan melalui penelitian yang dilakukan baik dalam negeri maupun di luar negeri diantaranya sebagai berikut: Nopiyanti (2012) dalam penelitianya mengenai pengembangan perangkat pembelajaran berbantuan GeoGebra pada materi geometri menunjukan bahwa perangkat yang dibuat memberikan dampak terhadap meningkatnya keterlibatan siswa dalam pembelajaran. Retno (2014) membuktikan bahwa terdapat perbedaan kemampuan penalaran matematis siswa yang pembelajarannya menggunakan model kooperatif tipe STAD berbantuan GeoGebra dibandingkan dengan siswa yang menggunakan model pembelajaran kooperatif tipe STAD tanpa berbantuan GeoGebra. Ramadhani (2016) membuktikan bahwa peningkatan kemampuan pemecahan masalah matematis siswa yang memperoleh PBL berbantuan GeoGebra lebih tinggi daripada siswa yang memperoleh pembelajaran tanpa bantuan GeoGebra. Da Silva \& Braz Figueiredo (2013) menunjukkan bahwa $83 \%$ dari siswa mengembangkan aktivitas tanpa kesalahan dalam representasi yang membuktikan bahwa GeoGebra yang digunakan di kelas Geometri sangat relevan untuk memahami materi. Araújo Cunha \& Lima Santos (2013) menyimpulkan bahwa penggunaan GeoGebra memberikan kesempatan siswa untuk mencoba berdiskusi suatu penemuan dan membangkitkan keingintahuan siswa. Berdasarkan berbagai hasil penelitian tersebut disimpulkan bahwa penggunaan GeoGebra dapat meningkatkan hardskill maupun softskill siswa.

GeoGebra dapat dikatakan sebagai program perangkat lunak geometri dinamis yang mempelajari tentang titik, segmen garis, garis, irisan kerucut dan konsep- konsep matematika serupa (Aktumen, Baltaci, dan Yildiz, 2011). Tran, Giang Nguyen, Duc Bui, dan Hung Phan (2014) menjelaskan bahwa software GeoGebra adalah dinamis, membantu penemuan, memungkinkan guru dan siswa untuk mengetahui solusi dari masalah geometris, dan dapat menciptakan banyak masalah baru.

Dari pendapat di atas, GeoGebra dapat digunakan untuk mengadakan eksplorasi dalam menemukan konsep yang akan dipelajari oleh siswa. Dengan demikian pembelajaran lebih berfokus kepada siswa, dimana siswa tidak menerima konsep secara langsung dari Guru. Beaumont (2010) pada intinya menjelaskan bahwa kegiatan penemuan, pemecahan masalah dan diskusi, dapat mengembangkan kemampuan berpikir kritis siswa. Menurut Ruseffendi (2006) kegiatan penemuan dan pemecahan masalah dapat mengembangkan kemampuan berpikir kreatif siswa. Sementara itu Runisah, Herman, dan Dahlan (2016) serta 
Runisah, Herman, dan Dahlan (2017) telah melakukan penelitian dengan menggunakan pembelajaran Learning Cycle $5 E$ yang merupakan pembelajaran yang berbasis eksplorasi telah membuktikan bahwa penggunaan model pembelajan tersebut dapat meningkatkan kemampuan berpikir kritis, kreatif, dan kemandirian belajar siswa. Dengan demikian berdasarkan pendapat dan hasil penelitian tersebut, GeoGebra dapat digunakan sebagai sarana eksplorasi untuk mengembangkan kemampuan berpikir kritis, kreatif, dan kemandirian belajar siswa.

Menurut Hohenwarter \& Fuchs (2004) GeoGebra sangat bermanfaat sebagai media pembelajaran matematika dengan beragam aktivitas sebagai berikut:

a. Sebagai media demonstrasi dan visualisasi konsep-konsep matematika rtentu.

b. Sebagai alat bantu untuk memvisualisasikan konstruksi konsep matematika tertentu, misalnya mengkonstruksi lingkaran dalam maupun lingkaran luar segitiga, atau garis singgung.

c. Sebagai alat bantu proses penemuan suatu konsep matematis, misalnya tempat kedudukan titik-titik atau karakteristik suatu grafik parabola

Selanjutnya, menurut Hohenwarter dan Jones (2007) keberadaan GeoGebra merupakan hal yang penting dalam membuat koneksi antara geometri dan aljabar dalam kurikulum sekolah dengan potensi dan kemampuannya dalam pendidikan matematika. Berdasarkan kelebihan tersebut dimana satu konsep dikaitkan dengan konsep lain maka akan terjadi belajar bermakna dimana siswa tidak hanya menghapal konsep-konsep matematika secara terpisah dan siswa benar-benar memahami terhadap konsep yang dipelajarinya.

Dengan melihat berbagai keunggulan yang dimiliki GeoGebra baik secara teoritis maupun didasarkan hasil penelitian maka pembuatan suatu desain pembelajaran matematika dengan menggunakan Software GeoGebra merupakan hal yang penting dilakukan. Namun demikian berdasarkan uraian di atas kemampuan guru dalam menggunakan software terutama GeoGebra masih kurang, sementara itu tenaga teknis Laboratorium Komputerpun tidak ada. Oleh karena itu diperlukan pelatihan tentang penggunaan GeoGebra dan cara mendesain pembelajaran dengan Geogebra. Hal ini dapat dilakukan pada kelompok guru yang tergabung ke dalam MGMP mengingat:

a. Guru mampu mengoperasikan komputer dengan baik.

b. Guru mempunyai Notebook atau laptop

c. Guru memiliki minat yang tinggi terhadap perkembangan media pembelajaran berbasis TIK.

d. Guru cukup potensial untuk dilatih mendisain pembelajaran berbasis TIK, salah satunya menggunakan software GeoGebra.

e. Berdasarkan uraian diatas dapat disimpulkan bahwa, sekolah mempunyai beberapa permasalahan terkait dengan permasalahn IPTEK yaitu:

f. Tidak ada teknisi khusus bidang TIK di sekolah

g. Guru tidak memiliki software pembelajaran matematika.

h. Guru tidak mahir dalam memanfaatkan software-software matematika yang ada di Internet.

\section{Permasalahan Mitra}

Beberapa masalah yang dihadapi guru-guru SMP dan MTs yang tergabung dalam MGMP terkait dengan pemanfaatan TI dalam pembelajaran adalah 
pengetahuan dan kemampuan guru yang kurang dalam memanfaatkan software software matematika dalam pembelajaran, khususnya software GeoGebra. Pemanfaatan teknologi hanya terbatas pada penggunaan power point dalam pembelajaran. Sementara itu dari pihak sekolahpun tidak ada teknisi khusus bidang TIK yang dapat memberikan masukan atas kekurangan yang dimiliki guru dalam memanfaatkan TIK.

Pembelajaran yang memanfaatkan GeoGebra memungkinkan interaksi siswa dengan siswa dan interaksi siswa dengan guru yang dilakukan melalui disain pembelajaran berbasis GeoGebra yang bisa berbentuk tulisan, suara, warna, gambar, gerak, simulasi, dan sebagainya. Prinsip yang digunakan ini, sejalan dengan prinsip belajar conditioning operan, belajar melalui serangkaian stimulusrespon dan belajar bermakna (Konstruktivisme)

Hal ini sejalan dengan kurikulum 2013 ataupun kurikulum nasional yang diberlakukan oleh pemerintah Indonesia. yaitu kurikulum berbasis sains dan teknologi, dimana pembelajaran harus dikaitkan dengan teknologi. Teknologi dimanfaatkan sesuai dengan materi pelajaran dan sebagai teknologi interaksi pembelajaran antara guru dan siswa. Dengan demikian, pengabdian pada masyarakat ini adalah program untuk membekali guru melaksanakan kurikulum 2013. Untuk mengatasai permasalahan yang ditemukan pelatihan guru dalam menggunakan GeoGebra dipilih sebagai salah satu solusi. Hal ini dikarenakan GeoGebra memiliki berbagai keunggulan baik secara teoritis maupun didasarkan hasil penelitian sebagaimana telah dijelaskan pada bagian sebelumnya. Selain itu GeoGebra mudah digunakan guru dan dapat dengan mudah diperoleh secara on line.

Melalui kegiatan PKM ini, para guru mendapatkan:

a. penyegaran tentang peranan media dalam pembelajaran matematika,

b. tambahan pengetahuan tentang media pembelajaran virtual yang baik,

c. Mendapatkan pelatihan tentang mendesain pembelajaran

matematika dengan menggunakan software GeoGebra.

\section{Tujuan}

Tujuan dari kegiatan pengabdian kepada masyarakat ini adalah:

a. untuk meningkatkan pengetahuan dan pemahaman guru tentang pentingnya media dalam pembelajaran matematika

$b$. untuk menghasilkan Guru yang mampu mendesain pembelajaran matematika dengan menggunakan software GeoGebra.

\section{B. METODE}

Pengembangan perangkat lunak dalam sistem pembelajaran bermakna (konstruktivisme) sangat diwarnai oleh Model-model pembelajaran berbasis IT. Pembelajaran berbasis IT dengan sofware GeoGebra bermanfaat untuk membantu guru dalam mengajar dan membantu siswa dalam belajar. Dalam pemanfaatan komputer sebagai Computere Basic Instruction (CBI) ini terdapat 3 metode yang dilakukan, yaitu: tutorial, workshop, dan simulasi.

Pelatihan diberikan kepada guru-guru anggota MGMP Matematika Kecamatan Sindang Kabupaten Indramayu. Adapun kegiatan-kegiatan yang akan dilakukan secara garis besar adalah sebagai berikut: 
Tabel 1. Kegiatan Pelatihan

\begin{tabular}{|l|l|}
\hline \multicolumn{1}{|c|}{ Kegiatan } & \multicolumn{1}{c|}{ Deskripsi Kegiatan } \\
\hline $\begin{array}{l}\text { Tutorial, latihan/ } \\
\text { praktek }\end{array}$ & $\begin{array}{c}\text { Menjelaskan tentang mendesain pembelajaran. } \\
- \\
\text { Menjelaskan penggunaan software GeoGebra } \\
\text { dalam pembelajaran matematika. }\end{array}$ \\
\hline $\begin{array}{l}\text { pendampingan/ } \\
\text { konsultasi }\end{array}$ & $\begin{array}{l}\text { Pembimbingan dalam membuat disain pembelajaran } \\
\text { berbasis IT dengan software GeoGebra } .\end{array}$ \\
\hline Simulasi & $\begin{array}{l}\text { Peserta mempraktekkan hasil disain pembelajaran yang } \\
\text { dirancang. }\end{array}$ \\
\hline Evaluasi & $\begin{array}{l}\text { Evaluasi terhadap kegiatan yang telah dilakukan secara } \\
\text { Keseluruhan }\end{array}$ \\
\hline
\end{tabular}

Untuk mengevaluasi keberhasilan pelaksanaan program diantaranya dengan menilai kemampuan guru peserta pelatihan dalam mendesain pembelajaran matematika melalui pengumpulan hasil kerja tersebut. Selain itu diadakan simulasi pada kelas matematika untuk melihat bagaimana guru melaksanakan pembelajaran di kelas matematika dengan desain pembelajaran berbantuan Geogebra yang telah dibuatnya. Setelah selesai simulasi dilakukan diskusi untuk menganalisis kelemahan-kelemahan yang ada baik dari media pembelajaran yang digunakan maupun dalam hal ketepatan menggunakannya dalam pembelajaran.

Setelah kegiatan PKM selesai, kegiatan pelatihan penggunaan Geogebra direncanakan menjadi salah satu agenda dalam kegiatan MGMP. Pelatihan tersebut diperuntukan untuk para anggota MGMP yang belum mengikuti pelatihan, dalam hal ini guru yang sudah memperoleh pelatihan menjadi tutor bagi guru yang lain. Selain itu, Tim PKM memberikan kesempatan kepada guru-guru yang memerlukan tambahan materi atau yang memperoleh permasalahan untuk mengadakan konsultasi.

\section{HASIL DAN PEMBAHASAN}

\section{Hasil}

Pelaksanaan pelatihan ini dilakukan di ruang auditorium universita Wiralodra. Kegiatan dilaksanakan dalam 1 hari yaitu tanggal 2018. Materi awal yang disampaikan yaitu teori tentang pembelajaran, pentingnya media pembelajaran, media pembelajaran virtual (mathlet), dan pemanfaatan GeoGebra dalam pembuatan mathlet. Kegiatan awal disajikan pada gambar 


$\begin{array}{ll}\text { ABDI WIRALODRA } & \text { ISSN 2656-5501 (Print) } \\ \text { JURNAL PENGABDIAN KEPADA MASYARAKAT } & \text { E-ISSN }\end{array}$

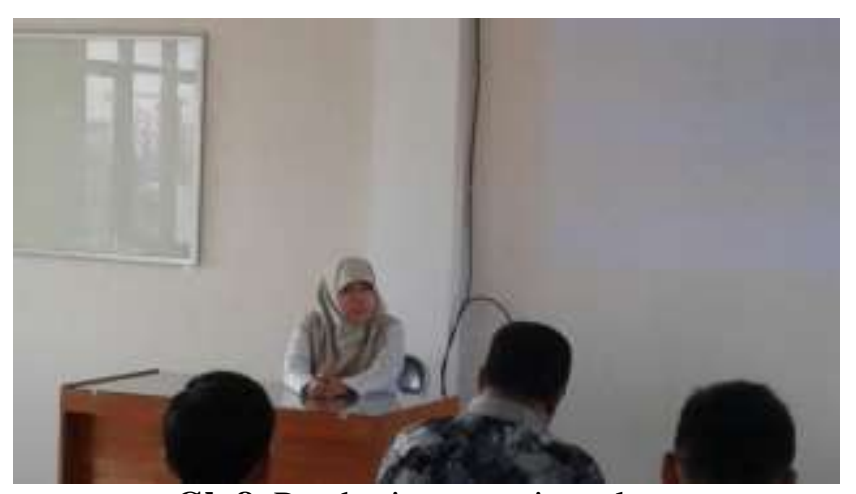

Gb 8. Pemberian materi awal

Gambar 8 memperlihatkan pemateri menjelaskan teori belajar secara umum, pentingnya media pembelajaran khususnya media GeoGebra. Selanjutnya praktek penggunaan GeoGebra langsung diberikan oleh pemateri/instruktur yang diikuti oleh para guru seperti disajikan pada Gambar 2 dan Gambar 3.

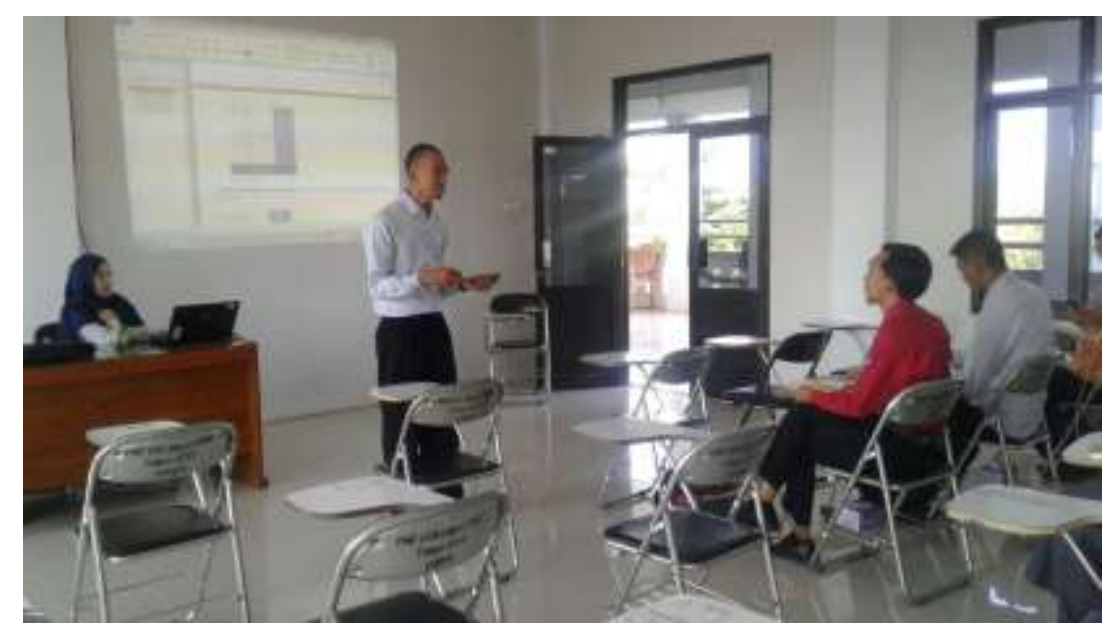

Gb. .9. Beberapa pemateri sedang memberikan instruksi pemakaian Geogebra

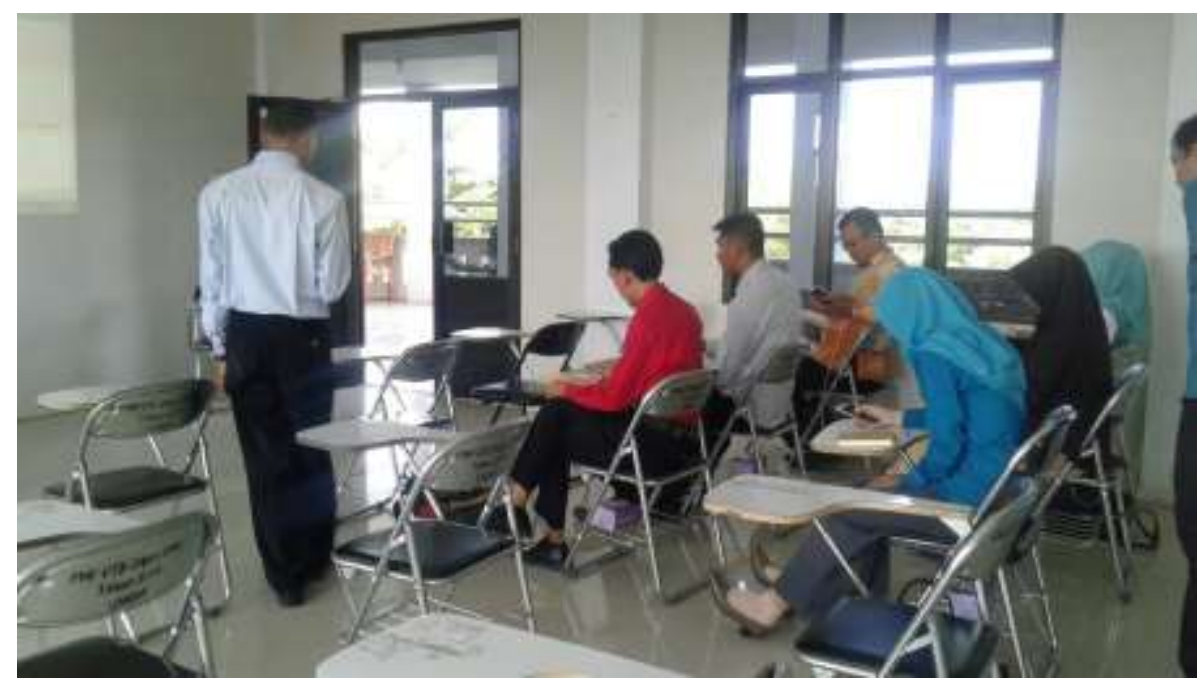

Gb. 10. Peserta mencoba Geogebra melalui HP Android dipandu oleh Pemateri

Gambar 9 memperlihatkan pemateri sedang mempraktekan penggunaan GeoGebra 
yang diperhatikan dengan seksama dan penuh antusias oleh para guru. Pada gambar 10 diperlihatkan guru mempraktekan langsung penggunaan GeoGebra dibawah bimbingan pemateri.

Materi yang disampaikan adalah Pengenalan GeoGebra dan Pemanfaatannya sebagai alat untuk membuat media pembelajaran matematika. Secara rinci materi yang dibahas pada bagian ini adalah sebagai berikut:

a. Penggunaan dasar GeoGebra,

b. Menggambar VS Mengkonstruksi,

c. Mengkonstruksi persegipanjang,

d. Mengkonstruksi Segitiga Samasisi,

e. Mengakses properties suatu objek,

f. Latihan: Mengkonstruksi Segitiga Samakaki,

g. Mengkonstruksi Persegi,

h. Lingkaran luar suatu segitiga,

i. Kotak Input,

j. Slider,

k. Fungsi Kuadrat,

Setelah pemberian materi-materi di atas, berikut adalah contoh produk yang dihasilkan guru



Gambar 11. Media Teorema Pythagoras

Tentu saja gambar di atas pada kenyataan bersifat dinamis, bukan statis, artinya gambar-gambar tersebut bisa dimanipulasi dan dieksplorasi. Titik-titiknya bisa di drag, dan sejalan dengan proses drag tersebut semua nilai yang berkaitan dengan titik tersebut akan berubah secara dinamis.

\section{Pembahasan}

Selama kegiatan pelatihan ini ini, para guru tampak terlibat sangat antusias .Banyak pertanyaan muncul terutama pada saat praktek penggunaan GeoGebra. Hasil pengamatan menunjukkan bahwa para guru masih kesulitan dalam menentukan konsep yang cocok dibuatkan media GeoGebra nya. Mereka masih sangat dipengaruhi oleh konsep pembuatan presentasi dengan powerpoint, dimana 
semuanya berjalan secara otomatis, tanpa keterlibatan siswa dalam mengeksplorasinya. Paradigma inilah yang pertama-tama harus diubah. Siswa perlu melakukan eksplorasi secara aktif dalam rangka mengkonstruksi konsep yang dipelajari sehingga konsep tersebut menjadi bermakna bagi mereka. Hal ini sejalan dengan paham konstruktivisme dari Piaget bahwa siswa membangun pengetahuan pada dirinya, artinya guru tidak memberikan materi secara langsung kepada siswa.selain itu kegiatan yang melibatkan siswa untuk mengeksplorasi untuk menemukan ide ide baru ataupun memecahkan masalah akan meningkatkan kreativitas siswa (Novita dan Putra, 2016; Ruseffendi, 2006)

Akhirnya setelah kegiatan berakhir terungkap bahwa waktu kegiatan yang hanya 1 hari sangatlah kurang untuk mempelajari GeoGebra secara lebih memadai. Masih banyak hal yang perlu diketahui dari GeoGebra untuk bisa memanfaatkannya dalam membuat media pembelajaran.

\section{KESIMPULAN DAN SARAN}

\section{Kesimpulan}

Berdasarkan hasil kegiatan PKM ini

a. Pengetahuan dan pemahaman guru tentang pentingnya media dalam pembelajaran matematika meningkat,

b. Guru mampu mendesain pembelajaran matematika dengan menggunakan software GeoGebra.

\section{Saran}

Beberapa hal yang dapat disarankan dari kegiatan PKM ini adalah:

a. Waktu pelaksanaan kegiatan perlu ditambah,

b. Penggunaan media pembelajaran eksploratif dalam pembelajaran matematika perlu ditingkatkan,

c. Mengingat pentingnya media dalam pembelajaran matematika, maka kegiatan PKM ini perlu diperluas agar menjangkau lebih banyak guru.

\section{REFERENSI}

Aktumen, M, Baltaci, S. Yildiz, A .(2011). Calculating the surface area of the water in a rolling cylinder and visualization as two and three dimensional by means of GeoGebra. International Journal of Computer Applications 25(1): $42-46$.

Araújo Cunha, J.G. \& Lima Santos, A (2013). Associating a mathematics model to a real situatuon with GeoGebra. Journal Of The Brazilian Conference Of GeoGebra (JBCG).1 ( 1 ): 22-34.

Beaumont, J. (2010). A sequence of critical thinking tasks. TESOL Journal.1(4): 427-448. Da Silva, A. B. \& Braz Figueired, A.P.N.(2013). A geometry class in high school with GeoGebra. Journal Of The Brazilian Conference Of GeoGebra (JBCG).1 (1 
): 2- 12 .

Hohenwarter, M. \& Fuchs, K. (2004). Combination of dynamic Geometry, Algebra, and Calculus in the software system GeoGebra http://archive.GeoGebra.org/static/publications/pecs_2004pp 3 diakses tanggal 3 Mei 2016.

Hohenwarter, M \& Jones, K. (2007). Ways of linking geometry and algebra: the case of GeoGebra. Proceedings of British Society for Research into Learning Mathematics. Vol. 27 No. 3. November 2007: London. Hal. 126131

Nopiyanti, P.A (2012). Pengembangan perangkat pembelajaran Geometri berbantuan GeoGebra dalam upaya meningkatkan keterlibatan dan prestasi belajar Matematika siswa kelas VII. Tesis. Universitas Pendidikan Ganesha, Bali.

Novita R and Putra M (2016) Using Task Like Pisa' S Problem To Support Student' S Math. Educ. 7 31-42

Ramadhani, R. (2016). Peningkatan kemampuan pemecahan masalah matematika siswa SMA melalui model Problem Based Learning berbantuan software GeoGebra. Jurnal ilmiah Integritas. 2(1): 67-82.

Retno, S. (2014). Peningkatan kemampuan penalaran dan koneksi matematis melalui penerapan model pembelajaran kooperatif tipe STAD berbantuan software GeoGebra (Studi Eksperimen Di SMAN 1 Cikulur Kabupaten Lebak Propinsi Banten). Jurnal Pendidikan dan Keguruan.1(1):1-11.

Runisah, Herman, T., dan Dahlan,J,A. (2016). The enhancement of students'creative thinking skills in mathematics through The 5E Learning Cycle with Metacognitive technique, International Journal of Education and Research, 14 (7): 347-368.

Runisah, Herman, T., dan Dahlan, J,A. (2017). The enhancement of students'critical thinking skills in mathematics through The 5E Learning Cycle with Metacognitive Technique, Advances in Social Science, Education and Humanities Research (ASSEHR), 57: $101-\quad 106 . \quad$ http://www.atlantispress.com/php/pub.php?publication=icmsed-16. Diakses tanggal 10 Maret 2017.

Runisah, Herman, T., dan Dahlan, J,A. (2017). Using the 5E Learning Cycle with Metacognitive Technique to enhance students'mathematical critical thinking skills. International Journal on Emerging Mathematics Education. (IJEME) 1 (1): 87-98

Ruseffendi, E.T. (2006). Pengantar kepada Membantu Guru Mengembangkan Kompetensinya dalam Pengajaran Matematika Untuk Meningkatkan CBSA. Tarsito. Bandung

Tran ,T, Giang Nguyen, N, Duc Bui, M, and Hung Phan, A. (2014).Discovery learning with the help of the GeoGebra dynamic geometry software. International Journal of Learning, Teaching and Educational Research. 7(1) : 44- 57. 